\title{
Analisis Intership Bagi Peningkatan Kompetensi Mahasiswa
}

\author{
Dinar Dinasty Lutfia dan Dedi Rianto Rahadi \\ ${ }^{2}$ Program Studi Manajemen, President University. Jalan Kihajar Dewantara, Kota \\ Bekasi, Jawa Barat, 17530, Indonesia. \\ E-Mail : ${ }^{1}$ dinar.lutfia@student.president.ac.id, dedi1968@president.ac.id
}

Submitted: AGUSTUS 2020

Accepted: NOVEMBER 2020

\begin{abstract}
The most important aspect in undergoing an internship (internship) is to produce students who are more ready to undergo the world of work and professionally, which is carried out through internship activities. With internship activities, students can find out what skills they have so far. This study aims to determine the effect of internships on student competencies. This type of research uses qualitative research, namely, the data obtained is theory development and describes theory. The data collection technique was carried out using observation and interviews which were conducted through question and answer between the researcher and the resource person. The results of the case studies show that the internship program has a very meaningful role or contribution for students to improve the competence of soft skills \& hard skills. And it also shows that the habits and attitudes that students have are very important compared to the knowledge and skills that can be obtained in a short time and increasing student competence through apprenticeship programs can reach professional standards and serve as a provision for experience for working in the next place.
\end{abstract}

Keywords : Internship, competence, soft skill, hard skill

\begin{abstract}
ABSTRAK
Aspek terpenting didalam menjalani internship (magang) adalah untuk menghasilkan mahasiswa yang lebih siap menjalani dunia pekerjaan dan profesional, yang dilakukan dengan kegiatan internship. Dengan kegiatan internship mahasiswa bisa mengetahui skill apa saja yang selama ini mereka punya. Penelitian ini bertujuan untuk mengetahui pengaruh internship (magang) terhadap kompetensi yang dimiliki mahasiswa. Jenis penelitian ini menggunakan penelitian kualitatif yaitu, data yang diperoleh merupakan pengembangan teori \& mendeskripsikan teori. Teknik pengumpulan data dilakukan menggunakan observasi dan wawancara yang dilakukan melalui tanya jawab antara peneliti dan narasumber. Hasil studi kasus menunjukan bahwa program magang (internship) mempunyai peran atau kontribusi yang sangat berarti bagi para mahasiswa untuk meningkatkan kompetensi soft skills \& hard skills. Dan juga menunjukkan bahwa habit dan attitude yang dimiliki mahasiswa sangat berperan penting dibanding knowledge dan skill yang bisa didapatkan dalam waktu singkat dan peningkatan kompetensi mahasiswa melalui program magang bisa mencapai standar profesi dan dijadikan sebagai bekal pengalaman untuk kerja di tempat selanjutnya.
\end{abstract}

Kata Kunci :Magang, kompetensi, soft skill, hard skill

\section{PENDAHULUAN}

Meningkatnya lulusan perguruan tinggi baru (fresh graduate) setiap tahunnya di Indonesia menjadi salah satu masalah yang kita hadapi, karena pasalnya kemampuan atau skill yang dimiliki masih belum cukup sempurna atau butuh pelatihan khusus lagi

\section{JIMKES}

$$
\begin{array}{r}
\text { Jurnal Ilmiah Manajemen } \\
\text { Kesatuan } \\
\text { Vol. } 8 \text { No. 3, 2020 } \\
\text { pp. 199-204 } \\
\text { IBI Kesatuan } \\
\text { ISSN 2337-7860 } \\
\text { E-ISSN 2721 - 169X }
\end{array}
$$


Internship and Students'

Competencies seperti misalnya melakukan pendidikan tambahan selama beberapa tahun. Oleh karena itu hal yang bisa dilakukan universitas untuk menghasilkan individu-individu yang benarbenar terampil, memiliki skill dan siap bekerja setelah lulus, maka diadakan salah satu program tambahan kepada mahasiswa saat mereka menempuh studi S1 yaitu dengan melalui kegiatan kuliah kerja magang di perusahaan.

Magang adalah kegiatan pelatihan ataupun kursus yang dilakukan oleh mahasiswa untuk meningkatkan kompetensi soft skill yang dimiliki. Magang yang dilakukan oleh mahasiswa tidak hanya dapat memberikan manfaat kepada mahasiswa yang mengikuti proram magang, tetapi dengan kegiatan magang juga perusahaan bisa mendapat banyak manfaat, salah satunya bisa meningkatkan citra perusahaan di mata orang banyak. Selain itu, Kwan (Kipreos, 2016) juga berpendapat dengan menerima mahasiswa untuk melakukan program magang di perusahaannya itu bisa memberikan peluang kepada perusahaannya untuk merekrut karyawan baru jadi perusahaan bisa lebih menghemat biaya yang harusnya dikeluarkan untuk melakukan perekrutan.

Beberapa penelitian pun sudah membuktikan bahwa dengan melakukan kegiatan magang, dapat meningkatkan kompetensi yang dimiliki oleh peserta yang sedang mengikuti program magang. Menurut Tagala (2018) kompetensi adalah pembawaan dari seorang individu yang berkaitan dengan kinerja seseorang terhadap pekerjaannya.Penelitian yang dilakukan oleh Rugaiyah (2011) menyimpulkan bahwa program magang dapat meningkatkan kemampuan soft skills yang dimiliki oleh mahasiswa. Soft skills tersebut yang dimaksud antara lain seperti, kemampuan berkomunikasi dengan baik di lingkungan sekitar, kemampuan beradaptasi, kemampuan mengelola kerja tim, kemapuan bersosialisasi, dan ketelitian dalam bekerja.

Di Indonesia sudah banyak universitas yang mewajibkan untuk melakukan internship sebagai salah satu syarat kelulusan, contohnya saja President University yang sudah mengeluarkan kebijakan kepada mahasiswa nya yaitu mahasiswa nya diwajibkan mengikuti kegiatan internship di perusahaan sejak semester 9 . Kewajiban yang ditetapkan diharapkan bisa memberikan peningkatan kompetensi yang dimiliki oleh individu. Karena pasalnya menurut pendiri President University yaitu SD Darmono menyatakan jika dia ingin memiliki visi untuk membentuk skill, attitude, knowledge, dan habit mahasiswanya melalui teori dan praktik kerja, agar President University bisa menjadi contoh yang baik untuk universitas lainnya. Jika 4 hal tersebut dikuasai oleh mahasiswa maka menurutnya pasti lulusan President University bisa mendapatkan gaji yang maksimal sesuai dengan kemampuan yang ia miliki.

Di perusahaan didalam mengelola karyawan, training termasuk yang mendapat perhatian seperti petinggi HR. Karena banyak diantara mereka yang masih memerlukan pengetahuan dan informasi tentang training, seperti mana yang harus didahulukan antara hard skill dan soft skill. Menurut salah satu responden six sigma pada tahun 2008 menyatakan bahwa soft skill seperti komunikasi, interpersonal, leadership dan lain-lain ialah hal yang paling penting dibandingkan dengan hardskill.

Soft Skills dianggap menjadi penting karena ini menyangkut masalah sikap dan perilaku karyawan, munculnya perilaku yang buruk di perusahaan bisa sangat mempengaruhi pekerjaan. Attitude yang buruk tidak bisa terus kita pelihara didalam diri karena itu semua akan memiliki dampak negatif terhadap lingkungan ,pekerjaan, dan lainnya. Berbeda dengan hard skills yang lebih menekankan pada kemapuan teknis. Seperti finance, planning, budgeting, kemampuan ber bahasa asing, dan lain-lain. Dengan menjalankan internship/magang yang sudah ditetapkan dari universitas, kegiatan internship ini mengarahkan kepada mahasiswa guna untuk membentuk kepribadian dan kompetensi mahasiswa. Jadi, setelah mahasiswa lulus \& telah mengikuti program magang diharapkan mereka bisa memiliki keterampilan \& kompetensi kepribadian. Setelah selesai dengan menjalankan berbagai kegiatan yang telah diprogramkan secara baik, maka mahasiswa dianggap telah melaksanakan program magang sehingga diharapkan mereka memenuhi persyaratan kompetensi yang ditetapkan.

Berdasarkan latar belakang masalah yang telah dijelaskan diatas maka rumusan masalah didalam penelitian ini adalah :1. Apakah internship (magang) yang dilakukan 
oleh mahasiswa berperan penting peningkatan kompetensi mahasiswa?2. Kompetensi apa saja yang dibutuhkan oleh perusahaan? dan berdasarkan data diatas yang telah disesuaikan, penelitian ini memiliki tujuan yang mengarah kepada: 1 . Untuk mengetahui pengaruh peran internship terhadap kompetensi mahasiswa.2. Untuk mengetahui keterampilan atau hal apa saja yang didapat setelah melaksanakan program magang.

\section{METODE PENELITIAN}

Dalam penelitian ini penulis melakukan penelitian melalui wawancara terhadap 2 orang alumni President University dengan memberikan beberapa pertanyaan yaitu seperti: kebijakan apa yang mereka terima dari perusahaan selama magang? dibagian apa mereka bekerja? dan pertanyaan khusus kepada salah satu perusahaan: adakah kebijakan khusus yang diberikan kepada mahasiswa yang sedang magang?

Didalam penelitian ini juga penulis menggunakan penelitian kualitatif yaitu, penelitian yang dibuat bersifat deskriptif karena data yang diperoleh merupakan pengembangan teori dan mendeskripsikan teori dan lebih cenderung menggunakan analisis, dengan melakukan penelitian studi kasus terhadap President University tentang keterkaitan internship dengan kompetensi yang dimiliki mahasiswa.

Data penelitian berasal dari Data Sekunder, yaitu data yang didapatkan tidak secara langsung dari objek atau subjek penelitian. Teknik pengumpulan data dilakukan dengan melalui observasi yaitu merupakan kegiatan pengamatan terhadap suatu objek dengan melakukan pencarian di berbagai macam artikel, jurnal, dan situs internet lain, dan teknik pengumpulan data juga dilakukan melalui wawancara yang dilakukan melalui tanya jawab antara peneliti dan narasumber.

\section{HASIL \& PEMBAHASAN}

Menurut pendiri President University \& Jababeka Group, SD Darmono, mengatakan bahwa : "Poin yang saya perhatikan attitude dan habit karena knowledge dan skill bisa diberikan dalam waktu singkat. Sekarang universitas memberikan knowledge, skill hampir tidak ada, kecuali fakultas tertentu. Itu pun kalau punya peralatan," ujar Darmono saat berkunjung ke kantor Redaksi Kompas.com, Jakarta, Selasa (23/7/2019).

Darmono mengatakan jika mahasiswa memiliki habit dan attitude yang sangat baik itu sangat baik, karena itulah yang dibutuhkan oleh per industrian saat ini.

Universitas President University berusaha memenuhi kebutuhan masyarakat di sekitar dengan mencoba untuk memberi solusi antara teori/materi dan praktik yang dilakukan saat kuliah. "Makanya kami manfaatkan pabrik-pabrik sebagai tempat magang. President University dibangun untuk memenuhi kebutuhan dua pasar, yaitu orang ingin S1 tapi bisa magang di perusahaan sehingga waktu lulus sudah ada pengalaman kerja, bisa Bahasa Inggris, sehingga dapat gaji lebih tinggi," jelas Darmono.

\section{Analisis Internship Terhadap Peningkatan Kompetensi}

Pada umumnya mahasiswa hanya mendapatkan pengetahuan di bangku kuliah, tetapi sebenarnya pengetahuan juga bisa didapat melalui program magang atau internship. Ketika kita magang kita jadi lebih bisa mengetahui secara menyeluruh kegiatan di perusahaan, seperti membuat laporan, dan lain-lain.

Secara khusus tujuan magang adalah:

1. Meningkatkan kemampuan untuk menerapkan pengetahuan dan ketrampilan yang dimiliki.

2. Meningkatkan pengetahuan dalam kerja baik dalam hal keilmuan maupun pengalaman kerja.

3. Meningkatkan kemampuan berkomunikasi dengan orang-orang yang berada satu perusahaan dengan kita.

4. Memacu motivasi mahasiswa untuk menjadi tenaga kerja yang siap kerja dan menerapkan materi yang pernah dipelajari kedalam dunia pekerjaan.

5. Membuka peluang untuk memperoleh pengalaman praktis dalam kerja bagi mahasiswa.

\section{Internship and \\ Students' \\ Competencies}

201 
Internship and Students'

Competencies

202
6. Menciptakan keterkaitan dan kesepadanan antara perguruan tinggi dengan dunia kerja.

7. Memberi hubungan kerja sama yang baik antara universitas dengan dunia usaha. Karena pasti dari adanya hubungan baik perusahaan terhadap universitas akan menghasilkan hal yang saling menguntungkan dan menghasilkan hal yang positif untuk kedepannya.

Pemberian bekal yang masih dibutuhkan mahasiswa untuk meningkatkan pengetahuan dalam kegiatan magang antara lain: mahasiswa diberikan pengarahan terlebih dulu sebelum magang, jurusan menjelaskan secara detail kegiatan yang akan dilakukan di tempat magang, dosen pembimbing memberikan bimbingan dengan sungguh-sungguh pada mahasiswa, materi aplikasi komputer lebih diperdalam, perencanaan dan pelaksanaan magang lebih terkoordinir, dalam pemberian mata kuliah disesuaikan dengan kondisi riil di lapangan, dan pada mata kuliah manajemen kurikulum dan manajemen sarana dan prasarana lebih diperdalam.

Program magang mempunyai peran atau kontribusi yang sangat berarti bagi para mahasiswa untuk meningkatkan kompetensi soft skills \& hard skills. Menurut Henry Tamzel soft skill adalah sesuatu yang sudah ada didalam diri seseorang sejak lahir atau bisa dibilang soft skill mirip seperti bakat.Sedangkan Hard Skill (technical skill)adalah kemampuan yang memerlukan pelatihan khusus didalam diri seseorang. Jadi dapat disimpulkan hard skill adalah kemampuan untuk menguasai teknologi. Dan soft skill dan hard skill yang dimiliki seseorang saling sangat memiliki keterkaitan. Contohnya saja jika kita memiliki knowledge yang sangat baik di tempat bekerja tetapi attitude yang dimiliki sangat buruk seperti, tidak jujur, sering datang terlambat ke kantor, dan lain-lain. Jika itu terjadi itu bisa merusak reputasi diri kita sendiri.

Berdasarkan hasil wawancara saya terhadap alumni lulusan President University dapat saya simpulkan bahwa mereka diwajibkan mengikuti program internship pada saat semester 9, sebagai salah satu faktor kelulusan. Rata-rata dari mereka ketika mengikuti program internship mereka tidak mendapatkan kebijakan khusus dari perusahaan, dan berdasarkan hasil wawancara, job yang mereka dapat pun beragam karena kebanyakan rata-rata dari mereka internship berbeda dengan jurusannya, ada yang internship dibagain admin, hrd, sampai ke bagian pengurusan pajak, mereka mendapat job yang berbeda dari jurusan karena kebanyakan dari mereka mengisi job dari karyawan yang sedang cuti, seperti misalnya cuti hamil, dan lain-lain.

Dan untuk hasil wawancara terhadap salah satu perusahaan tentang adakah kebijakan khusus yang diberikan kepada mahasiswa yang sedang magang, jawabannya menurut salah satu perusahaan adalah yang penting mahasiswa tersebut mau bekerja sesuai aturan yang ada dan memiliki attitude yang baik. Dengan kegiatan magang yang telah dilakukan mahasiswa bisa memberikan banyak perubahan yang terjadi setelah magang, seperti contohnya lebih mengasah soft skill dan hard skill yang mereka punya, siap untuk menghadapi era global dalam melihat dunia pendidikan, dan dunia pekerjaan yang berlangsung dengan begitu cepat.

Mahasiswa juga bisa banyak memperoleh keterampilan ketika mereka melaksanakan kegiatan magang diperusahaan dan juga mahasiswa dapat memperoleh kompetensi kepribadian dalam melaksanakan program magang diantaranya:

1) Menambah portofolio dan daftar pengalaman. Ketika magang nantinya kita akan mendapatkan real project yang bisa dijadikan nilai tambahan dan pengalaman yang nantinya akan sangat berguna jika nantinya kita ingin melamar ditempat pekerjaan, dan tambahan portofolio akan memudahkan kita diterima bekerja.

2) Pengalaman dan skill yang semakin baik. Dengan kita melakukan internship/ magang kita bisa mengasah kemampuan soft skill dan hard skill kita yang mungkin selama ini terpendam. Dan dengan adanya kemampuan skill yang meningkat tentunya akan memudahkan kita juga untuk diterima di perusaahaan, terutama perusahaan yang sudah memiliki standar dan kredibilitas tinggi.

3) Menambah relasi kerja. Dengan melakukan internship mahasiswa bisa mendapatkan relasi yang lebih luas, karena secra otomatis mereka juga mendapatkan banyak teman 
yang bisa memberikan peluang dan kesempatan lain. Terutama membangun relasi dengan bidang yang sedang diminati olehnya. Jika sudah memiliki relasi yang luas kita tidak perlu bingung untuk mencari pekerjaan, karena gabungan dari soft skill, hard skill, dan relasi yang kita miliki itu sudah cukup untuk membuat kita dipermudah ketika ingin mendapatkan pekerjaan.

4) Menemukan passion yang ada pada diri kita. Mungkin sebelum kita melakukan internship kita tidak pernah tahu passion apa yang sebenarnya kita miliki, karena mungkin kurang kita asah, tetapi dengan internship para mahasiswa bisa menemukan passion yang selama ini terpendam. Jika kita sudah menemukan passion yang kita miliki tentunya itu akan membuat kita lebih mudah untuk mencari pekerjaan yang sesuai dengan passion yang dimiliki.

5) Peluang karir yang lebih baik. Dengan melakukan internship otomatis kita akan mendapatkan banyak pengalaman, teman dan relasi yang dapat memberikan informasi dan ilmu lainnya, sehingga dari situ kita bisa belajar apa yang belum kita ketahui, dan membuat kompetensi kita semakin meningkat untuk pekerjaan, dan memberikan peluang yang lebih besar untuk bisa diterima kerja di perusahaan yang ingin dicapai.

\section{PENUTUP}

Mahasiswa adalah salah satu faktor penerus bangsa, dalam menghadapi era globalisasi ini mahasiswa berperan penting dalam melihat peluang untuk kemajuan bangsa dan kemajuan diri sendiri. Dalam melihat peluang mahasiswa harus cerdik untuk melihat kesempatan apa saja yang ada di sekitar untuk meningkatkan kemampuan diri, seperti contohnya pada zaman sekarang mungkin sudah harus bisa dan terbiasa dalam berbicara menggunakan bahasa inggris, itu bukan hal yang asing lagi, mungkin rata-rata sekarang perusahaan sudah menjadikan kemampuan berbicara bahasa asing sebagai salah satu faktor diterima kerja. Oleh karena itu, sistem pembelajaran di universitas ataupun perguruan tinggi harus bisa berorientasi/sejalan dengan kebutuhan didunia kerja. Mahasiswa diharapkan bisa lebih peka dan terus mengasah kemampuan diri sendiri setinggi mungkin agar siap menghadapi era globalisasi.

Untuk menciptakan mahasiswa dengan kualitas yang baik, tentunya program magang sangat diperlukan, selain untuk menererapkan teori dan praktik saat kuliah program magang juga untuk menunjang kualitas mahasiswa dengan melakukan pemberian bekal sebaik mungkin, program magang juga memegang peranan dan kontribusi penting untuk mahasiswa nantinya yang akan terjun ke dunia pekerjaan yaitu, untuk meningkatkan kompetensi yang mereka miliki. Peningkatan kompetensi mahasiswa melalui program magang bisa mencapai standar profesi dan dijadikan sebagai bekal pengalaman untuk kerja di tempat selanjutnya. Mahasiswa juga dapat memperoleh kompetensi kepribadian atau soft skill seperti: sikap \& perilaku, cara berkomunikasi, kemampuan ber adaptasi, kemampuan bersosialisai, dan lainnya. Kompetensi tersebut dapat diaplikasikan di pekerjaan yang akan dimiliki mahasiswa nantinya.

\section{DAFTAR PUSTAKA}

[1] Artaya, Putu I, dan I Gede Arimbawa. 2008. Pengaruh Kuliah Kerja Magang Terhadap Peningkatan Kompetensi Mahasiswa. Jurnal Ekonomi. 8(2): 110-112.

[2] Hamdani. 2018. "Pentingnya Memiliki Kompetensi di Era Globalisasi”.http://blog.poltekkutaraja.ac.id/hamdani/2018/03/27/pentingnyamemiliki-kompetensi-di-era-globalisasi/. (27 Maret 2018).Hutapea, Erwin. 2019. Seimbangkan Teori dan Praktik Kuliah Ini Solusi President University. KOMPAS.com. 24 Juli.

[3] Jonathan. "Pengertian Kompetensi: Definisi, Jenis-Jenis, dan Manfaat Kompetensi.https://www.maxmanroe.com/vid/manajemen/pengertiankompetensi.html tahun akses 2020. 
Internship and Students'

Competencies

204
[4] Manurung, T.M.S., 2017. Pengaruh motivasi dan perilaku belajar terhadap prestasi akademik mahasiswa. JAS-PT (Jurnal Analisis Sistem Pendidikan Tinggi Indonesia), 1(1), pp.17-26.

[5] Muanas, M. and Wijayantri, A.C., 2010. Evaluasi Atas Penerapan Sistem Online Payment Point Pos (SOPPOS) Dalam Kaitannya Dengan Efisiensi Kegiatan Operasional Pada PT Pos Indonesia (Persero). Jurnal Ilmiah Ranggagading (JIR), 10(1), pp.28-31.

[6] Munawar, A. and Purba, J.H.V., 2006. Kajian Dampak Pelatihan terhadap Kinerja Karyawan. Jurnal Ilmiah Kesatuan Nomor, 8(7), p.2.

[7] Munawar, A., 2020, May. Determinants of Corporates Leverage in Indonesia. In 2nd International Seminar on Business, Economics, Social Science and Technology (ISBEST 2019) (pp. 302-306). Atlantis Press

[8] "Penelitian Kualitatif". Wikipedia. Ensiklopedia Bebas. 26 Agustus 2020. Web. 21 Oktober

2020. https://id.wikipedia.org/w/index.php?title=Penelitian_kualitatif\&oldid=17 337961Purwaningsih, Ika Juni Sartika, Sri Witurachmi, dan Renata Zoraifi. 2017.

Soft Skills Pada Pelaksanaan Magang Dunia Usaha/Dunia Industri. Surakarta: Universitas Sebelas Maret. Jurnal Tata Arta. Volume 3, Nomor 2, https://core.ac.uk/download/pdf/297862098.pdf. 19 Oktober 2020.

[9] Pamungkas, B., Flassy, D.A., Yudanto, S., Rachman, H.A., Rahayu, S., Komarudin, S. and Setijono, H., 2018. Accrual-based accounting implementation in Indonesian's local governments compared to other countries' experiences. Man in India, 98(1), pp.1-23.

[10] Rugaiyah.2011.Pengembangan Kompetensi Mahasiswa Melalui Magang. Jurnal Manajemen Pendidikan. 212-217.

[11] Sari, Febriani. 2019. "Manfaat Magang Bagi Kamu Generasi Milenial".https://www.gamelab.id/news/81-manfaat-magang-bagi-kamu-generasimilenial.(8 Maret 2019).tahun akses 2020.

[12] Sugianto,Ronny. 2016. "Metode Pengumpulan Data dalam Penelitian". http://ciputrauceo.net/blog/2016/2/18/metode-pengumpulan-data-dalampenelitian tahun akses 2020 .

[13] Universitas Psikologi. 2020. "Pengertian, Dimensi, dan Jenis-Jenis Kompetensi Menurut Para Ahli". https://www.universitaspsikologi.com/2020/03/pengertiandimensi-dan-jenis-jenis-

kompetensi.html\#: :text=Menurut\%20Wibowo\%20(2013)\%20kompetensi\%20adal ah,yang\%20dibebankan\%20kepadanya\%20dalam\%20organisasi.\&text=Kompetens i\%20memiliki\%20peran\%20yang\%20amat,seseorang\%20dalam $\% 20$ melakukan $\% 20$ suatu\%20pekerjaan. tahun akses 2020

[14] Situshttps://openlibrary.telkomuniversity.ac.id/pustaka/files/16077/bab1/lapora n-kegiatan-magang-di-pt-telekomunikasi-indonesia-divisi-consumer-service-baratunit-modern-channel-area-cirebon-periode-januari-februari-2012.pdf. tahun akses 2020. 